\title{
Financial Systems Theory and Control of Finances: Policy Initiatives for Access to Finance in Nigeria
}

\author{
CHISOM NDIGWE ${ }^{1}$, ALEXANDER EHIMARE OMANKHANLEN $^{2}$, AREGHAN $^{5}$ \\ ISIBOR $^{3}$, T.C. OKAFOR ${ }^{4}$, BENJAMIN IGHODALO EHIKIOYA $^{5}$ \\ ACHUGAMONU BEDE UZOMA ${ }^{6}$ \\ $1,2,3,4,5, \& 6$ Covenant University, Ota, NIGERIA
}

\begin{abstract}
The financial sector has witnessed several policy initiatives that have shaped the Nigerian financial system into what it is today. However, little study has been done on long-term effect of previous policies initiatives on the current loan access by firms, and this is the main objective of the study. The ARDL technique and error-correction model was used to check the long run effect of policy initiatives on loan in Nigeria utilizing data derived from the CBN statistical bulletin and world development index (1986-2019). Findings revealed that lending portfolio of deposit money banks has a negative and statistically significant relationship with domestic credit given to the private sector. In addition, the study recommended, amongst others, that regulatory authorities initiate policies that will create a platform for long term sustainable relationship with bankers and customers.
\end{abstract}

Keywords: - Financial Systems Theory, Control of Finances, Financial sector, Policy initiatives, Bank lending, Concentration Theories, Long-run effect, ARDL

Received: March 3, 2020. Revised: September 19, 2020. Accepted: September 30, 2020. Published: October 22, 2020.

\section{Introduction}

The ability of industrial firms to access loans from banks is dependent on the policies in place to obtain the funds. The ability to access finance in emerging economies like Nigeria is a major concern of individuals and institutions. Statistics have shown that over 90 per cent of businesses being run in Nigeria are small and medium enterprises which have the potential to become larger and alleviate poverty and unemployment [2]; [7]. However, the ability of those businesses to access finance is limited by the policies in place to obtain finance and even sustain loan repayment [5].

According to the [16], the smaller the business in Nigeria the less likely the ability of the business to access finances. Only one out of three businesses have a fifty percent chance of accessing finance due to the collateral policies in place and the inability of medium and small businesses to meet those standards [14]. On the flip side, deposit money banks are exposed to diverse risks and also greater levels of competition as they grow therefore policies are initiated to protect them from shocks that might occur and also protection of depositors' funds.
The banking industry is majorly responsible for lending of short term cash flows of businesses and firms given the fact that it is a player in the money market which is short term in nature. However, loans constitute over $80 \%$ of the source of profits of a bank and access to loans by firms help to prompt economic development [1]. As much as it is a necessity for financial institutions to make loans available to small firms that will enable their growth, it is also mandatory that they ensure that their loans are insured due to the fact that banks are custodians of depositors' funds [14]. The type of firm a bank lends to depend on the offshoot of the banks values and objectives. However, policies put in place by the monetary authorities go a long way to shape the goals of financial institutions and their lending policies.

The ability of firms to access finance is dependent on the policies initiated to govern the lending activities of the banks in the long run. Therefore, the research will show whether policy initiatives monetary authorities has positive long-run impact on access to finance in Nigeria. It analysed bank lending data during the period of consolidation reform by 
the $\mathrm{CBN}$ and an econometric analysis of the long-run effect of those policy initiatives on the access to finance in the Nigerian economy using data of 33 years to incorporate major policy reforms that have taken place in the financial industry.

\section{Literature Review}

Several policy initiatives and reforms have been instituted since the banking ordinance of 1952 which have continued to strengthen the banking system. In 1992, the industry experienced liberation from government control during which the industry experienced a greater need for reform due to deep financial distress. The industry after this, witnessed in 2000-2002, the introduction of Universal banking [12]; [13]. This enabled banks to engage in other banking and non- banking functions. However, this new-found freedom to engage in other functions made several banks neglect the core intermediation function [18]. There was the popular reform of 2004 which sought to not only strengthen the banking system and weed out the fringe players but also change the face of the banking system. The 2004- 2005 consolidation reform which followed the removal of government owned deposits from banks created a shock in the system. The reform championed by Charles Soludo led to the reduction of 89 to 25 banks in the industry [17]; [16]; [15]; [9]. The post-consolidation era of 2008 was period of testing for the banks that had made it through the consolidation era.

\subsection{Theoretical review of literature}

\subsubsection{Pro-Concentration Theory}

The supporters of increased concentration of banks contend that bank mergers and acquisitions drive up economies of scale and synergy consequently binging about increased effectiveness and efficiency of the system [3]; [4]. To support this, [4] analysed 122 U.S. banking organizations and found an indirect connection between size and the unpredictability of bank returns. Be that as it may, these discoveries are dependent on circumstances in which the consolidations were intentional, excluding the consolidation cases of 2004 in Nigeria. Advocates of this theory contend that a concentrated system of bigger banks is better as they can diversity and are less prone to shocks that a system of many small fragile banks and is easier to monitor [6]; [10].

\section{Model Specifications}

The study takes into consideration the consolidation reform of 2004 (which required banks to recapitalise and increase their capital base) which forms the basis for the study's variable selection and model specification. The study utilizes secondary data from the Central bank statistical bulletin for the years 19862016.

The theoretical framework of the analysis is based on the bank concentration theories. The expectation of the analysis is that, a result showing a positive long run relationship between the banking policies and access to finance will have a consensus with the proponents of the Pro-concentration theory and a negative long run relationship will have results in line with the pro-deconcentration theory. The theoretical framework enabled the study to adopt a model that represents the effect of policy initiatives on access to finance in Nigeria. The access to finance is represented by the variable $D C P$ which domestic credit to the private sector (source from the world development index) which serves as the dependent variable while the independent variables of the study are Lending portfolio for commercial banks (LPC) and Lending rate $(L E R)$ (both independent variables where sourced from the Central Bank statistical bulletin, 2016). The lending portfolio of commercial banks serves as a proxy for increased bank capitalization due to the consolidation reform and the lending rate (prime) serves as the minimum rate at which firms can access loans.

The study adopted the modified ARDL model of [1] and is specified as:

$$
\begin{aligned}
\Delta D C P_{t}= & \alpha_{0}+\Sigma \beta i \Delta D C P_{t-i}+\Sigma \gamma j \Delta L C P_{t-i}+ \\
& \Sigma \delta k \Delta L E R_{t-i}+\theta 0 D C P_{t-1}+ \\
& \theta 1 L C P_{t-1}+\theta 2 L E R_{t-1}+\mu_{t}
\end{aligned}
$$

The adopted and modified ECM model of [9] is stated as:

$$
\begin{aligned}
\Delta D C P_{t}= & \alpha_{0}+\Sigma \beta i \Delta D C P_{t-i}+\Sigma \gamma j \Delta L C P_{t-i}+ \\
& \Sigma \delta k \Delta L E R_{t-i}+\phi E C M_{t-i}+\mu_{t}
\end{aligned}
$$


$D C P=f(L C P, L E R)$

Credit to the private sector $(D C P)$

Lending portfolio for commercial banks ( $L P C)$

Lending rate $(L E R)$

\section{Data Analysis and Results}

\subsection{Augmented Dickey-Fuller (ADF) Unit root Test}

In order to test the data stationarity, the ADF unit root test was carried out and the result below in table 4.1 shows that the dependent variable is stationary at first difference while the independent variables were stationary at levels. Due to this result, the study analysed its data using the autoregressive distributed lag (ARDL) co-integration technique.

Table 4.1: Result of Unit Root Analysis using ADF

\begin{tabular}{|c|c|c|c|c|c|c|}
\hline VARIABLES & $\begin{array}{c}\text { ADF TEST } \\
\text { STATISTICS } \\
\text { AT LEVEL }\end{array}$ & $\begin{array}{c}5 \% \\
\text { CRITICAL } \\
\text { VALUES } \\
\text { AT } \\
\text { LEVELS }\end{array}$ & $\begin{array}{c}\text { ADF TEST } \\
\text { STATISTICS } \\
{\text { AT 1 } 1^{\text {st }}}^{\text {DIFFERENCE }}\end{array}$ & $\begin{array}{c}5 \% \\
\text { CRITICAL } \\
\text { VALUES AT } \\
1^{\mathrm{ST}} \\
\text { DIFFERENCE }\end{array}$ & $\begin{array}{c}\text { ORDER OF } \\
\text { INTEGRATION }\end{array}$ & REMARK \\
\hline$\overline{\mathrm{DCP}}$ & -2.574322 & -2.963972 & -4.796105 & -2.963972 & $\mathrm{I}(1)$ & $\begin{array}{c}1 \mathrm{st} \\
\text { DIFFERENCE }\end{array}$ \\
\hline LER & -3.238867 & -2.963972 & -2.862019 & -2.963972 & $\mathrm{I}(0)$ & LEVEL \\
\hline LPC & 3.578006 & -2.998064 & -2.720163 & -2.998064 & $\mathrm{I}(0)$ & LEVEL \\
\hline
\end{tabular}

Source: Author's Computation

\subsection{ARDL Bounds Test}

To analyze the long-run relationships among the variables, the research used the ARDL econometric method. The reason for the ARDL technique is because of the unit root test result which had all the variables stationary at both levels and first difference. The ARDL bounds test is mainly joint $\mathrm{F}$ statistic. The first step is model estimation using OLS. The OLS shows whether a longrun relationship exists in the model using Fstatistics. The null hypothesis of no cointegration is rejected when test statistic value exceeds the upper critical bounds value. The $\mathrm{F}$ - test result is shown below:

Table 4.1: ARDL Bounds Test

\begin{tabular}{|c|c|c|}
\hline Variables & F-Stats & \\
\hline F(DCP, LPC, LER) & $\mathbf{4 . 6 0 9 1 3 8}$ & \\
\hline Critical Value & Lower Bound & Upper Bound \\
\hline $1 \%$ & 4.13 & 5 \\
\hline $5 \%$ & 3.1 & 3.87 \\
\hline $10 \%$ & 2.63 & 3.35 \\
\hline
\end{tabular}

Source: Author's computation
From table above, there exists a long-run cointegrating relationship between $D C P$ and $L P C, L E R$. The F-stat (4.609138) is greater than the $5 \%$ and $10 \%$ upper bounds and lower bound at all levels of significance. This means we reject the null hypothesis.

\subsection{ARDL Long-Run Coefficients}

The estimation of the long-run equilibrium relationship between variables is carried out.

Table 4.4: Estimated Long Run Coefficients

\begin{tabular}{|c|c|c|c|c|}
\hline \multicolumn{5}{|c|}{ Dependent Variable: DCP } \\
\hline Variable & Coefficient & $\begin{array}{l}\text { Std. } \\
\text { error }\end{array}$ & t-stat & Prob. \\
\hline LPC & $-8.46 \mathrm{E}-04$ & $1.38 \mathrm{E}-04$ & $\begin{array}{c}- \\
6.144554\end{array}$ & 0.0000 \\
\hline LER & $4.99 \mathrm{E}-02$ & $1.54 \mathrm{E}-01$ & 0.324114 & 0.7510 \\
\hline $\mathrm{C}$ & -1.11899 & 3.35107 & 0.33392 & 0.7438 \\
\hline \multicolumn{5}{|c|}{$\mathrm{C}=\mathrm{DDCP}-\left(-0.0008^{*} \mathrm{LPC}+0.0499 * \mathrm{LER}-1.1190\right)$} \\
\hline
\end{tabular}

From the table above, the relationship DCP and $L P C$ is negative significant with t-stat of 6.144554. This means in the long run, increased portfolio of bank loans will have a negative relationship with domestic credit. Lending rate, $L E R$, has a positive long-run cointegrating relationship with DCP, and is 
significant at $5 \%$ significant level $(\mathrm{t}$-value $=$ $0.324114)$.

\subsection{Discussion of Findings}

Looking at the relationship between policy and access to finance, Central banks impose policy initiatives on the banking system to strengthen and improve their efficiency in carrying out their lending function. Therefore, an increased credit towards the private sector is expected to increase with favourable policy initiatives. From the estimation of the long-run relationship of the model, its shows that loan portfolio of commercial banks in the period of consolidation have negative significant relationship with domestic credit in the longrun. The negative impact implies that increased bank portfolio due to policy changes has negative relationship with credit to the private sector in the long-run. This means most bank loans are short term in nature. Also, banks portfolio contains investment in other areas like stock broking, and so on.

This result is in line with the prodeconcentration theory which states that policy changes that make for large banks for instance consolidation exercise do not necessarily make for more efficient banks due to the influence they can have over policy initiatives to work in their favor and not necessarily in the favor of the society, in this case the private sector. The error correction model gave a result showing fast adjustment to unfavorable changes of the independent variable at a rate of $250 \%$. The adjustment of the dependent variable to negative effect of the independent variable is very fast implying that negative effect of changes in independent variables due to variations in policies does not have a lasting impact on access to finance by the private sector.

\section{Conclusion and Recommendations}

In light of the discoveries above, it is presumed that an efficient banking system initiative is crucial for a sustainable banking industry. Monetary authorities should focus on implementing policy initiatives that engender long term relationships between banks and creditors.

Policy makers and bank regulators will be better equipped to coordinate their administrative control towards improving and reinforcing directions that will encourage the simplicity of getting to finance by small and developing businesses in the economy. The final product of this will be gainful banking activities as well as a more sustainable industry that enables the ease of accessing finance.

This study prescribes occasional increment in the banks' capitalization particularly since the hyper-inflationary rate in our economy isn't hinting at subsiding. This will manage the cost of the bank financial leverage to play out a portion of its key formative roles particularly in the real segment of the economy bringing about the muchwanted national monetary advancement.

\section{References}

[1] Aburime, S., Modelling the effects of banking sector reforms on bank management practices in Nigeria. Journal of Emerging Issues in Economics, Finance and Banking, Vol.2, No. 6, 2010, pp. 12-26.

[2] Achugamonu, B.U., Adegbite, E.O., Omankhanlen, A. E., Okoye, L.U., and Isibor A. Dynamics of digital finance and financial inclusion nexus in sub-Saharan Africa. Proceedings of the 33rd International Business Information Management Association Conference, IBIMA 2019: Education Excellence and Innovation Management through Vision 2020

[3] Afolabi, J., Mergers and acquisitions in the Nigerian banking system: Issues and challenges. Nigeria deposit insurance corporation, Vol. 7, No. 10, 2011, pp. 121.

[4] Agbaeze, E. K., \& Onwuka, I. O., Basel III and abolition of universal banking model-implication for Nigerian banks.Journal of Economics and Finance, Vol.2, No. 5, 2018, pp. 1-15.

[5] Akin, I., Ikpefan, O.A., \& Isibor, A.A., Credit to the private sector and economic growth in the present technological world: Empirical evidence from Nigeria. International Journal of Civil Engineering and Technology, Vol.10, No.2, 2019, pp. 2329-2347 
[6] Asogwa, R. C., Liberalization, Consolidation and Market Structure in Nigerian Banking, A Paper presented at the African Economic Research Consortium (AERC), Nairobi, 2003

[7] Basel committee on Bank supervision, (2010). Basel III - international framework for liquidity risk measurement, standards and monitoring. Bank for International Settlement. www.bis.org/publ/bcbs180.htm

[8] Central Bank Brief. (2014). Impact of the implementation of basel IIin the Nigerian banking sector,The Research Department Central Bank of Nigeria.15(2):1-10

[9] Ezike, J. E. (2013). Capital adequacy standards, basle accord and bank performance: The Nigerian experience (A case study of selected banks in Nigeria). Asian Economic and Financial Review, 3(2): 146-159.

[10] International Monetary Fund and World bank(2013). Financial Sector Assessment Program: Nigeria -Basel Core Principles for Effective Banking Supervision. World Bank, Washington, DC.https://openknowledge.worldbank.org /handle/10986/15968 License.

[11] Isibor, A.A., Felicia, O., Maria, A., Godswill, O., and Chisom, N. (2018). Exchange rate management and sectoral output performance. International Journal of Supply Chain Management, 7(5), pp. 129-134

[12] Isibor, A., Ojo, J. A. T., and Ikpefan, O. A. (2018). Does financial deregulation spur economic development in Nigeria? Peer-Reviewed Proceedings of the International Business Information Management Association Conference (31st IBIMA) held on 25-26 April 2018, Milan, Italy.

[13] Isibor, A., Ojo, J. A. T., and Ikpefan, O. A. (2018). A study of financial deepening and capital accumulation in Nigeria. PeerReviewed Proceedings of the International Business Information Management Association Conference (31st IBIMA) held on 25-26 April 2018, Milan, Italy.

[14] Isibor, A., Olokoyo, F. O., Arogundade, M., Osuma, G., and Ndigwe, C. (2018). Exchange rate management and sectoral output performance. Peer-Reviewed Proceedings of the International Business Information Management Association Conference (31st IBIMA) held on 25-26 April 2018, Milan, Italy.

[15] Omankhanlen, A.E., Ilori, N., Isibor, A. (2018). Monetary policies and the achievement of bank profit objective. Peer-Reviewed Proceedings of the International Business Information Management Association Conference (31st IBIMA) held on 25-26 April 2018, Milan, Italy.

[16] Omankhanlen, A., Okorie, U., Taiwo, J.N. (2015). A Dynamic Analysis of the Relationship between Monetary Policies and Loan Risk Exposures in Nigerian Deposit Money Banks. Mediterranean Journal of Social Sciences, 6(6):247-258.

[17] Soludo, C. (2004) Consolidating the Nigerian Banking Industry to Meet the Development Challenges of the 21st Century. An Address delivered to the Special Meeting of Bankers Committee, Abuja.

[18] Uduak, M., \& Ubong, E. (2015). Banking sector reforms and the performance of commercial banks in Nigeria. Journal of World Economic Research. 4(3):45-60.

\section{Creative Commons Attribution License 4.0 (Attribution 4.0 International, CC BY 4.0)}

This article is published under the terms of the Creative Commons Attribution License 4.0 https://creativecommons.org/licenses/by/4.0/deed.en_US 